\title{
Tindak Pidana Hak Cipta dan Problematika Penegakan Hukumnya
}

\author{
Hanafi
}

\begin{abstract}
Abstrak
The protection of the law for the intellectual property rights is one form of appreciation to a person who creates inovative works in the field of scientific and literary artistic works. Indonesia government has aftempled to protect intellectual property rights. By making the law of intelectual property rights, it is expected that violations against the law can be. minimized. In practice, however, the law does not work effectivelly and so infringements continue to develop.
\end{abstract}

\section{Pendahuluan}

Perlindungan hukum terhadap hak cipta pada dasarnya dimaksudkan sebagai upaya untuk mewujudkan iklim yang lebih baik bagi tumbuh dan berkembangnya gairah mencipta di bidang ilmu pengetahuan, seni, dan sastra. Menyadari akan hal tersebut, pemerintah Indonesia secara terus-menerus berusaha untuk memperbaharuj peraturan perundang-undangan di bidang hak cipta untuk menyesuaikan diri dengan perkembangan yang ada, baik perkembangan di bidang ekonomi maupun di bidang teknologi. Dilihat dari sejarahnya, pemberlakuan Ündang-undang hak Cipta di negara kita dimulai dengan ketentuan undangundang warisan kolonial, yaitu Auteurswet 1912. Undang-undang itu kemudian dicabut oleh undang-undang UU No.6 Tahun 1982 tentang Hak Cipta. Sehingga dapat dikatakan bahwa Undang-undang No.6 Tahun 1982 itu merupakan Undang-undang di bidang hak cipta yang pertama diberlakukan sesudah Indonesia mencapai kemerdekaan.

Terdapat beberapa perubahan dan pembaharuan di dalam UU No.6 Tahun 1982 apabila dibandingkan dengan Auteurswet 1912. Perubahan tersebut setidak-tidaknya menyangkut dua hal. Pertama, berkaitan dengan perluasan bidang karya cipta yang mendapat perlindungan; dan kedua, berkaitan dengan sanksi pidana, dulunya hanya pidana denda, dengan undang-undang yang baru, sanksi pidana itu dialternatifkan atau dikumulatifkan dengan pidana penjara.

Namun demikian, realitas menunjukkan bahwa pelanggaran hak cipta telah mencapai tingkat yang membahayakan dan dapat merusak tatanan kehidupan masyarakat pada umumnya dan minat mengarang pada khususnya. Unituk mengatasi dan menghentikan pelanggaran hak cipta itu dipandang perlu. 
menyempurnakan beberapa ketentuan dalam UU No.6 Tahun 1982, sehingga dibentuklah Undang-undang Hak Cipta yang baru, yaitu UU No.7 Tahun 1987 tentang "Perubahan atas Undang-undang No.6 Tahun 1982". Perubahan dari UU No.6 Tahun 1982 ke UU No.7 Tahun 1987 menyangkut adanya penambahan beberapa ketentuan, di antaranya mengenai ruang lingkup karya cipta yang dilindungi dengan menambahkan mengenai program komputer dan penambahan lama berlakunya hak cipta untuk semua kategori.

Dengan turut sertanya Indonesia menandatangani perjanjian WTO (World Trade International) termasuk perjanjian tantang TRIPS (Trade Related Aspects of Intelectual Property Rights), maka Undang-undang Hak Cipta kita pertu menyesuaikan diri untuk memenuhi kewajiban internasional yang sudah kita terima melalui kedua organisasi itu, termasuk di dalamnya adalah ketentuan yang berkaitan dengan perlindungan Hak Milik Intelektual. ${ }^{1}$ Untuk itu pemerintah Indonesia merasakan perlunya perubahan Undangundang U Hak Cipta sehingga dibentuklah UU No.12 Tahun 1997 yang merupakan perubahan atas UU No.6 Tahun 1982 yang telah diubah dengan UU No.7 Tahun 1987.

Usaha yang dilakukan oleh pemerintah - Indonesia dalam rangka perlindungan terhadap karya cipta ini ternyata tidak membuahkan hasil yang maksimal. UU Hak Cipta dalam memberikan perlindungan hukum terhadap suatu karya cipta maupun terhadap hak dan kepentingan pencipta dan pemegang hak cipta cukup bagus, bahkan dapat dikatakan agak berlebihan. Dalam realitasnya, pelanggaran hak cipta masih menggejala dan seolah-olah tidak dapat ditangani walaupun pelanggaran itu dapat dilihat dan dirasakan dalam kehidupan sehari-hari. Berbagai macam bentuk pelanggaran yang dilakukan dapat berupa pembajakan terhadap karya cipta, mengumumkan, mengedarkan, maupun menjual karya cipta orang lain tanpa seizin pencipta ataupun pemegang hak cipta. Dampak dari pelanggaran hak cipta ini di samping akan merusak tatanan masyarakat pada umumnya, juga akan mengakibatkan lesunya gairah untuk berkarya di bidang ilmu pengetahuan, seni, dan sastra. Dampak lainnya yang ditimbulkan adalah berkurangnya penghasilan/ pemasukan negara berupa pajak penghasilan yang seharusnya dibayar oleh pencipta atau pemegang hak cipta.

Mencermati uraian di atas, di satu pihak undang-undang sudah dapat dikatakan sempurna namun di pihak lain pelanggaran hak cipta tidak dapat dibendung, sehingga yang periu dikaji lebih jauh adalah mengenai penegakan hukum terhadap pelanggaran hak cipta itu. Secara konseptual, terdapat beberapa faktor yang mempengaruhi terhadap penegakan hukum ini, yakni faktor undang-undang, faktor aparat penegak hukum, faktor sarana yang tersedia, faktor masyarakat, dan faktor budaya. ${ }^{2}$ Kelima faktor itulah yang akan dijadikan sebagai pisau analisis mengapa pene-

'Sudargo Gautama dan Rizawanto Winata. 1998. Konvensi-konvensi Hak Milik Intelektual Baru Untuk Indonesia (1997). Bandung: Citra Aditya Bakti. Hlm.1.

${ }^{2}$ Soerjono Soekanto. 1983. Faktor-faktor Yang Mempengaruhi Penegakan Hukum. Jakarta: Rajawali Pers. Him.2. 
gakan hukum terhadap pelanggaran hak cipta secara kuantitas dapat dikatakan masih rendah.

Beberapa pokok masalah yang akan dibahas dalam tulisan ini adalah: pertama, ruang lingkup hak cipta; kedua, perlindungan hukum terhadap karya cipta; ketiga, tindak pidana hak cipta, dan yang ke empat, mengenai problematika penegakan hukum terhadap pelanggaran hak cipta.

\section{Ruang Lingkup Hak Cipta}

Ruang lingkup hak cipta meliputi karya cipta dalam bidang ilmu pengetahuan, karya seni dan sastra. Pengertian hak cipta menurut UU Hak Cipta adalah hak khusus bagi pencipta atau penerima hak untuk mengumumkan atau memperbanyak ciptaannya maupun memberi izin untuk itu dengan tidak mengurangi pembatasan-pembatasan menurut peraturan perundang-undangan yang berlaku. Maksud dari hak khusus itu adalah bahwa tidak ada orang lain yang boleh melakukan hak itu kecuali setelah mendapat izin dari si pencipta atau pemegang hak cipta. Dengan demikian hak cipta merupakan hak milik pribadi (personal property) yang bersifat khusus.

Secara hakiki hak cipta termasuk hak milik immateriil karena menyangkut ide, gagasan pemikiran, maupun imajinasi dari seseorang yang dituangkan dalam bentuk karya cipta, seperti buku ilmiah, karangan sastra, maupun karya seni. Menurut ketentuan UU Hak Cipta, hak cipta dianggap sebagai benda bergerak sehingga dapat beralih dan dialihkan baik seluruhnya atau sebagian dengan cara pewarisan, hibah, wasiat, dijadikan milik negara, dan dengan perjanjian, yang harus dilakukan dengan akta otentik. Hak cipta dari pencipta yang meninggal dunia menjadi milik ahli warisnya atau penerima wasiat.

UU Hak cipta mengenal istilah pencipta, pemegang hak cipta, dan ciptaan. Pencipta menurut UU Hak Cipta adalah seorang atau beberapa orang secara bersama-sama yang atas inspirasinya lahir suatu ciptaan berdasarkan kemampuan pikiran, imajinasi, kecekatan, ketrampilan atau keahlian yang dituangkan dalam bentuk khas dan bersifat pribadi. Sedangkan yang dimaksud dengan pemegang hak cipta adalah pencipta sebagai pemilik hak cipta atau orang yang menerima hak tersebut dari pencipta, atau orang lain yang menerima hak tersebut lebih lanjut dari orang tersebut di atas.

Pemegang hak cipta terhadap suatu karya cipta dalam bidang ilmu pengetahuan, seni, dan sastra, dapat dibedakan dalam empat kelompok:

1. Pencipta, baik sendiri atau secara bersamasama.

2. Lembaga atau instansi;

3. Badan hukum;

4. Negara.

Pencipta dianggap sebagai pemegang hak cipta apabila namanya terdapat dalam daftar umum ciptaan dan pengumúman resmi tentang pendaftaran pada Departemen Kehakiman, atau namanya disebut dalam ciptaan atau diumumkan sebagai pencipta pada suatu ciptaan (Pasal 5).

Dalam hal suatu ciptaan terdiri dari beberapa bagian tersendiri yang diciptakan oleh dua orang atau lebih, maka yang dianggap sebagai pencipta ialah orang yang memimpin serta mengawasi penyelesaian seluruh ciptaan itu, atau jika tidak ada orang itu, orang yang menghimpunnya, dengan tidak mengurangi 
hak cipta masing-masing atas bagian ciptaannya (Pasal 6)

Suatu ciptaan yang dirancang seseorang diwujudkan dan dikerjakan oleh orang lain di bawah pimpinan dan pengawasan orang yang merancang, maka yang dianggap sebagai penciptanya adalah orang yang merancang ciptaan itu (Pasal 7).

Apabila suatu ciptaan dibuat dalam. hubungan dinas dengan pihak lain dalam lingkungan pekerjaannya, maka si pembuat sebagai pencipta dan dinạs tersebut sebagai pemegang hak cipta. Jika suatu ciptaan dibuat dalam hubungan kerja dengan pihak lain dalam lingkungan pekerjaannya, maka pihak yang membuat karya cipta itu sebagai pencipta. adalah pemegang hak cipta, kecuali diperjanjikan lain. Badan hukum yang mengumumkan suatu ciptaan berasal daripadanya dengan tidak menyebut seseorang sebagai pencipta, maka badan hukum tersebut dianggap sebagai penciptanya kecuali dibuktikan sebaliknya (Pasal 8 dan 9).

Negara memegang hak cipta terhadap: - pertama, karya peninggalan pra sejarah, sejarah dan benda budaya nasional lainnya. Kedua, suatu ciptaan yang tidak diketahui penciptanya. Ketiga, hasil kebudayaan rakyat yang menjadi milik bersama seperti cerita, hikayat, dongeng, legenda, babad, lagu, kerajinan tangan, koreografi, tarian, kaligrafi, dan karya seni lainnya yang dipelihara dan dilindungi negara. Khusus untuk poin ketiga, negara memegang hak cipta hanya terhadap pihak luar negeri (Pasal 10 dan 10A).

\section{Perlindungan Hukum Terhadap Karya Cipta}

Jenis ciptaan yang mendapat perlindungan hukum dari UU No.12 Tahun 1997 yang merupakan perubahan atas UU No.6 Tahun 1982 tentang Hak Cipta sebagaimana telah diubah dengan UU No.7 Tahun 1987 (selanjutnya disebut UU Hak Cipta), meliputi ciptaan dalam bidang ilmu pengetahuan, seni, dan sastra yang mencakup karya:

a. Buku, program komputer, pamflet, susunan perwajahan karya tulis yang diterbitkan, dan semua hasil karya tulis lainnya;

b. Ceramah, kuliah, pidato, dan ciptaan lain- nya yang diwujudkan dengan cara diucapkan;

c. Alat peraga yang dibuat untuk kepentingan pendidikan dan ilmu pengetahuan;

d. Ciptaan lagu atau musik dengan atau tanpa teks, termasuk karawitan dan rekaman suara;

e. Drama, tari (koreografi), pewayangan, pantomim;

f. Karya pertunjukan;

g. Karya siaran;

h. Seni rupa dalam segala bentuk seperti seni lukis, gambar, seni ukir, seni kaligrafi, seni pahat, seni patung, kolase, seni terapan yang berupa seni kerajinan tangan;

i. Arsitektur,

j. Peta;

k. Seni batik;

l. Fotografi;

m. Sinematografi;

n. Terjemahan, tafsir, saduran, bunga rampai, dan karya lainnya dari hasil pengalih wujudan; 
Walaupun karya cipta yang disebutkan di atas mendapat perlindungan hukum yang tegas, tapi undang-undang juga memberikan pembatasan-pembatasan terhadap hak cipta. Pembatasan-pembatasan tersebut diatur dalam Pasal 13 dan Pasal 14. Ketentuan Pasal 13 menyebutkan, tidak dianggap sebagai pelanggaran hak cipta:

1. Pengumuman dan perbanyakan dari lembaga negara dan lagu kebangsaan menurut sifat aslinya;

2. Pengumuman dan perbanyakan dari segala sesuatu yang diumumkan oleh atau atas nama pemerintah, kecuali apabila hak cipta itu dinyatakan dilindungi, baik dengan peraturan perundang-undangan maupun dengan pernyataan pada ciptaan itu sendiri atau ketika ciptaan itu diumumkan;

3. Pengambilan, baik seluruhnya maupun sebagian, berita dari kantor berita, badan penyiar radio atau televisi dan surat kabar setelah satu kali dua puluh empat jam terhitung dari saat pengumuman pertama berita itu dan sumbernya harus disebut secara lengkap.

Kemudian dalam Pasal 14 disebutkan, dengan syarat bahwa sumbernya harus disebut atau dicantumkan, maka tidak dianggap sebagai pelanggaran hak cipta:

a. Penggunaan ciptaan pihak lain untuk keperluan pendidikan, penelitian, penulisan karya ilmiah, penyusunan laporan, penulisan kritik dan tinjauan suatu masalah dengan ketentuan tidak merugikan kepentingan yang wajar bagi pencipta.

b. Pengambilan ciptaan pihak tain baik seluruhnya maupun sebagian guna keper- luan pembelaan di dalam dan di luar pengadilan.

c. Pengambilan ciptaan pihak lain baik seluruhnya maupun sebagian guna keperluan:

a. ceramah yang semata-mata untuk tujuan pendidikan dan ilmu pengetahuan.

b. pertunjukan atau pementasan yang tidak dipungut bayaran dengan ketentuan tidak merugikan kepentingan yang wajar bagi pencipta.

d. Perbanyakan suatu ciptaan dalam bidang ilmu, seni, dan sastra dalam huruf braille guna keperluan tunanetra, kecuali jika perbanyakan itu bersifat komersial.

e. Perbanyakan suatu ciptaan selain program komputer, secara terbatas dengan cara atau alat apa pun atau proses yang serupa oleh perpustakaan umum, lembaga ilmu pengetahuan atau pendidikan dan pusat dokumentasi yang non komersial semata-mata untuk keperluan aktivitasnya.

f. Perubahan yang dilakukan atas karya arsitektur seperti ciptaan bangunan berdasarkan pertimbangan pelaksanaan teknis.

g. Pembuatan suatu salinan cadangian suatu program komputer oleh pemilik program komputer yang dilakukan semata-mata untuk digunakan sendiri.

\section{Tindak Pidana Hak Cipta}

\section{Jenis Tidak Pidana Hak Cipta}

Jenis tindak pidana hak cipta sebagaimana diatur di dalam ketentuan Pasal 44 Undang-undang No. 6 Tahun 1982 yang telah 
diubah dengan UU No.7 Tahun 1987 dan UU No. 14 Tahun 1997 tentang Hak Cipta meliputi:

a. Mengumumkan atau memperbanyak suatu ciptaan atau memberi izin untuk itu

Ketentuan mengenai delik ini terdapat dalam Pasal 44 ayat (1) yang berbunyi : "Barangsiapa dengan sengaja dan tanpa hak mengumumkan atau memperbanyak suatu ciptaan atau memberi izin untuk itu dipidana dengan pidana penjara paling lama 7 (tujuh) tahun dan atau denda paling banyak Rp.100.000.000. (seratus juta rupiah)".

Apabila kita cermati rumusan Pasal 44 ayat (1) di atas, terdapat beberapa unsur yang dapat dikenakan sebagai delik hak cipta, yaitu:

1) dengan sengaja;

2) tanpa hak;

3) mengumumkan atau memperbanyak suatu ciptaan atau memberi izin untuk itu.

Unsur pertama, yaitu dengan sengaja, artinya pelaku berbuat dengan penuh kesadaran dan mengerti bahwa perbuatan itu dilarang oleh undang-undang. Unsur ke dua, yaitu tanpa hak, artinya orang yaing memperbanyak atau mengumumkan ciptaan itu bukan seorang pencipta atau pemegang hak cipta. Sedangkan unsur ke tiga, mengumumkan atau memperbanyak, biasanya terwujud dalam bentuk pembajakan baik buku, cassete, ataupuñ program komputer.

b. Menyiarkan, memamerkan, mengedarkan atau menjual kepada umum suatu ciptaan atau barang hasil pelanggaran hak cipta;
Ketentuan mengenai delik ini terdapat dalam Pasal 44 ayat (2) yang berbunyi: "Barangsiapa dengan sengaja menyiarkan, memamerkan, mengedarkan atau menjual kepada umum suatu ciptaan atau barang hasil pelanggaran hak cipta sebagaimana dimaksud ayat (1), dipidana dengan pidana penjara paling lama 5 (lima) tahun dan atau denda paling banyak Rp.50.000.000. (lima puluh juta rupiah)".

Berdasarkan Pasal 44 ayat (2) maka unsurunsurnya adalah sebagai berikut:

1) dengan sengaja;

2) menyiarkan, memamerkan, mengedarkan, atau menjual kepada umum;

3) barang hasil pelanggaran hak cipta.

Pasal ini memfokuskan pada orang yang menjual barang hasil pelanggaran hak cipta. Ancaman pidana terhadap pelaku delik ini cukup tinggi, yakni 5 tahun pidana penjara dan atau denda paling banyak lima puluh juta rupiah. Mencermati ancaman pidana terhadap. kedua pasal tersebut di atas, rumusan ancaman pidana yang digunakan oleh pembentuk undang-undang adalah berbentuk alternatif-kumulatif. Artinya, hakim dapat menjatuhkan pidana penjara saja atau pidana denda saja, atau kedua-duanya, yaitu penjara dan denda sekaligus. ${ }^{3}$

c. Dengan sengaja melanggar Pasal 16 , yaitu mengumumkan setiap ciptaan yang bertentangan dengan kebijaksanaan Pemerintah di bidang pertahanan dan keamanan negara, kesusilaan serta ketertiban umum.

3Leden Marpaung. 1995. Tindak Pidana Terhadap Hak Atas Kekayaan Intelektual. Jakarta: Sinar Grafika. HIm. 20. 
Hakikat dari Pasal 44 ayat (3) ini adalah bahwa si pelaku tidak mematuhi larangan. Mengumumkan kebijaksanaan pemerintah di bidang pertahanan dan keamanan merupakan hal yang layak mendapat larangan karena hal tersebut menyangkut kepentingan nasional. Di bidang kesusilaan sebenarnya sudah diatur secara tersendiri di dalam KUHP sehingga pengaturan di dalam UU Hak Cipta ini menurut hemat penulis kurang tepat. Ancaman pidana terhadap pelanggaran pasal ini adalah pidana penjara paling lama 3 tahun dan atau denda paling banyak 25 juta rupiah.

d. Dengan sengaja melanggar Pasal 18 , yaitu mengumumkan atau memperbanyak potret seseorang tanpa izin.

Ketentuan Pasal 18 yang dimaksud adalah:

(1) Pemegang hak cipta atas potret seseorang, untuk memperbanyak atau mengumumkan ciptaannya, harus terlebih dahulu mendapat izin dari orang yang dipotret, atau dalam jangka waktu 10 (sepuluh) tahun sesudah orang yang dipotret meninggal dunia mendapat izin ahli warisnya.

(2) Jika suatu potret memuat 2 (dua) orang atau lebih, maka untuk perbanyakan atau pengumuman masing-masing yang dipotret, apabila pengumuman atau perbanyakan itu memuat juga orang lain dalam potret itu, pemegang hak cipta terlebih dahulu mendapat izin dari masing-masing dalam potret itu, atau dalam jangka waktu 10 (sepuluh) tahun sesudah yang bersangkutan meninggal dunia dengan mendapat izin ahli waris masing-masing.

(3) Pasal ini berlaku atas potret yang dibuat:

a. atas permintaan sendiri dari yang dipotret; b. atas permintaan yang dilakukan atas nama orang yang dipotret;

c. untuk kepentingan orang yang dipotret.

Adapun ancaman pidana terhadap pelanggaran pasal ini adalah pidana penjara paling lama 2 tahun dan atau denda paling banyak 15 juta rupiah.

\section{Anatomi Kejahatan di bidang Hak Cipta}

Tindak pidana hak cipta biasanya dilakukan oleh perorangan maupun badan hukum yang berkaitan dengan bidang ekonomi dan perdagangan. Motifnya adalah untuk mencari keuntungan yang sebesar-besarnya dengan cara melanggar hukum. Modus operandinya yang terbanyak adalah menggandakan dalam jumlah yang besar untuk dijual kepada masyarakat. Adapun alat yang digunakan berteknologi cukup canggih, seperti alat-alat komputer, mesin-mesin industri, alat-alat kimia, alat transportasi, serta dokumen-dokumen penunjang lainnya guna mensukseskan usaha mereka. Hasil produksi bajakannya pun sangat baik, sehingga sulit untuk membedakan antara karya cipta yang asli dengan hasil bajakan.

Lokasi untuk melakukan tindak pidana hak cipta pada umumnya dilakukan di lokasi pabrik pembuatan hasil produksinya dan di rumah-rumah perorangan yang diariggap aman dan dilakukan secara sembunyi-sembunyi. Korban atau sasaran mereka adalah pencipta ataupun pengusaha/pedagang yang memegang hak cipta dari pencipta untuk memperbanyak ciptaan dari penciptanya. Kasus yang pernah masuk ke pengadilan Negeri Jakarta Timur adalah kasus menggandakan buku sebanyak 38 judul buku bajakan milik 19 
penerbit. Dalam kasus ini yang menjadi korban adalah pencipta karangan buku itu dan penerbit sebagai pemegang hak cipta.

Dampak adanya tindak pidana hak cipta secara umum sudah demikian besarnya terhadap tatanan kehidupan bangsa di bidang ekonomi, hukum, dan sosial budaya. Di bidang sosial budaya, dampak yang timbul semakin meluasnya pembajakan tersebut 'begitu beraneka ragam. ${ }^{4}$

Bagi para pelaku tindak pidana atau para pembajak, keadaan yang berlarut-larut tanpa adanya tindakan yang tegas akan semakin menimbulkan sikap bahwa pembajakan sudah merupakan hal yang biasa dan tidak lagi merupakan tindakan yang melanggar undangundang. Bagi para pencipta, keadaan tersebut semakin menumbuhkan sikap apatis dan sangat. menurunkan gairah mencipta. Bagi penerbit, akan kehilangan minatnya dalam profesi mereka untuk menerbitkan buku.

Bagi masyarakat sebagai konsumen, semakin pula tumbuh sikap yang tidak lagi memandang perlu untuk mempertanyakan apakah sesuatu barang tersebut merupakan hasil pelanggaran hukum atau tidak. Makin tumbuh sikap acuh tak acuh mengenai yang baik dan yang buruk, apa yang sah dan tidak sah, kendati negara kita adalah negara yang berdasarkan atas hukum. Bagi negara, dengan banyaknya bajakan atau tindak pidana di bidang hak cipta, maka dilihat dari sektor penerimaan/pendapatan negara melalui pajak penghasilan dari hak cipta, jelas bahwa negara 'sangat dirugikan, karena tidak memperoleh pemasukan/pendapatan dari sektor itu yang cukup potensial sebagai salah satu sumber dana untuk pembangunan.

Khusus yang menyangkut ciptaan asing, apabila terjadi tindak pidana hak cipta, dampaknya akan berakibat negatif terhadap pembinaan hubungan antarnegara terutama yang menyangkut bidang perdagangan, yang pada gilirannya akan sangat merugikan dan berpengaruh luas bagi peningkatan ekspor non migas yang tengah kita galakkan.

\section{Problematika Penegakan Hukumnya}

Hukum pidana mempunyai objek penggarapan mengenai perbuatan melawan hukum yang sungguh-sungguh terjadi maupun perbuatan melawan hukum yang mungkin akan terjadi. Bekerjanya hukum pidana didukung dan dilaksanakan oleh alat perlengkapan negara yang biasanya disebut aparatur penegak hukum yang tata kerjanya-pun bisa 'unique' dalam suatu sistem penegakan hukum. ${ }^{5}$

Mahadi mengartikan penegakan hukum sebagai hal menegakkan atau mempertahankan hukum oleh para penegak hukum apabila telah terjadi pelanggaran hukum atau diduga hukum akan atau mungkin dilanggar. ${ }^{6}$ Secara mudah dapat dikatakan bahwa penegakan hukum itu suatu sistem aksi atau sistem proses.?

“Widyopramono. 1992. Tindak Pidana Hak Cipta Analisis dan Penyelesaiannya. Jakarta: Sinar Grafika. Him. 25-26.

5Bambang Poernomo. 1988. Kapita Selekta Hukum Pidana. Yogyakarta: Liberty. HIm.90.

"Mahadi. 1982. "Peranan Kesadaran Hukum dalam Proses Penegakan Hukum". Kertas Kerja Simposium Penegakan Hukum di BPHN. Jakarta: Binacipta. Hlm.90.

'Bambang Poernomo. 1984. Orientasi Hukum Acara Pidana. Yogyakarta: Amarta Buku. HIm.119. 
Menurut Satjipto Rahardjo, hukum itu diam, hukum memuat janji-janji, hukum mengandung ide atau konsep yang tergolong abstrak. Hanya melalui penegakannya oleh penegak hukum maka hukum itu dapat diekspresikan atau dikonkritkan. Jadi penegakan hukum dapat dikatakan sebagai suatu proses untuk mewujudkan keinginan-keinginan hukum menjadi kenyataan. Yang dimaksud keinginan hukum di sini tidak lain adalah pikiran badan pembuat undang-undang yang dirumuskan dalam peraturan hukum itu. ${ }^{8}$

Penegakan hukum sebagai usaha menjalankan hukum dapat mempunyai arti sempit, arti luas, dan arti yang tidak terbatas. Dalam arti sempit penegakan hukum adalah menjalankan hukum oleh polisi, sebagaimana pengertian orang awam tentang hukum. Dalam arti luas penegakan hukum ialah menjalankan hukum oleh alat-alat perlengkapan negara, yakni kepolisian, kejaksaan, kehakiman. Sedangkan pengertian tidak terbatas adalah tugas dari pembentuk undang-undang, hakim, jaksa, pengacara, aparat pemerintah pamong praja, lembaga pemasyarakatan, dan aparat eksekusi, serta setiap orang yang menjalankan hukum yaitu badan resmi dan setiap orang yang bersangkutan dengan proses berjalannya hukum. ${ }^{9}$

Dalam karya tulis ini penegakan hukum hanya dibatasi pada pengertian yang terbatas, yaitu meliputi polisi, jaksa, hakim serta instansi resmi yang terkait di dalamnya. Hukum pidana dalam pengertian materiil memuat pasal-pasal yang melarang dilakukannya suatu perbuatan tertentu disertai ancaman pidana bagi barangsiapa yang melanggar larangan tersebut..10 Seperti telah disebutkan di atas bahwa hukum itu diam dan hanya dengan penegakannya oleh aparat penegak hukum maka hukum itu dapat diekspresikan atau direalisasikan. Jadi penegakan hukum itu sangat penting artinya dalam rangka menjamin ditaatinya peraturan yang berlaku.

Pemberlakuan hukum pidana terhadap kasus pelanggaran hak cipta bukan tidak menimbulkan masalah. Banyak hambatan yang dihadapi oleh aparat penegak hukum dalam menegakkan Undang-undang Hak Cipta. Permasalahan tersebut mencakup baik permasalahan yuridis maupun non-yuridis. Seperti diketahui bahwa hukum itu tidak berdiri sendiri. Banyak faktor yang menyertainya yang dapat berpengaruh terhadap bekerjanya hukum. Kalau demikian, dapat dikatakan bahwa masalah pokok dari penegakan hukum sebenarnya terletak pada faktor-faktor yang mungkin berpengaruh.

Secara konsepsional gangguan terhadap penegakan hukum disebabkan oleh ketidakserasian antara nilai, kaidah, dan pola perilaku. Nilai adalah pandangan manusia mengenai apa yang baik dan apa yang buruk. Nilai bersifat abstrak dan memerlukan penjabaran lebih konkrit yang menjelma menjadi kaidah. Kaidah merupakan pedoman bagi manusia dalam bertingkah laku yang dianggap pantas atau yang seharusnya. Perilaku atau sikap tindak

${ }^{8}$ Satijpto Rahardjo. Tanpa Tahun. Masalah Penegakan Hukum Suatu Tinjauan Sosiologis. Bandung: Sinar Baru. HIm.24.

${ }^{9}$ Bambang Poernomo. 1984. Op.Cit. HIm.120.

${ }^{10}$ Moeljatno. 1984. Asas-asas Hukum Pidana. Jakarta: Bina Aksara. HIm.1. 
tersebut bertujuan untuk menciptakan, memelihara, dan mempertahankan kedamaian."

Ada beberapa faktor yang dapat mempengaruhi bekerjanya hukum. Menurut Soerjono Soekanto faktor-faktor tersebut adalah:

1. Faktor hukumnya sendiri, yang dalam tulisan ini dibatasi pada UU Hak Cipta;

2. Faktor penegak hukum yakni fihak-fihak yang membentuk dan menerapkan hukum

3. Faktor sarana atau fasilitas yang mendukung penegak hukum;

4. Faktor masyarakat, yakni lingkungan di mana hukum itu berlaku atau diterapkan;

5. Faktor kebudayaan, yakni sebagai hasil karya, cipta, dan rasa yang didasarkan pada karsa manusia di dalam pergaulan hidup. ${ }^{12}$

\section{ad.1. Faktor Hukum / Undang-undang}

Undang-undang Hak Cipta dalam memberikan perlindungan hukum karya cipta maupun terhadap hak dan kepentingan pencipta dan pemegang hak cipta cukup bagus, bahkan agak berlebihan. Hal ini terlihat dari dua aspek. Pertama, perubahan sifat delik dari delik aduan menjadi delik biasa. Kedua, ancaman pidana yang cukup berat terhadap pelanggar delik hak cipta.

Dari segi sifat delik, yang semula delik aduan berubah menjadi delik biasa, menunjukkan keseriusan undang-undang dalam menanggulangi tindak pidana'ini. Dari segi ruang lingkup jenis pelanggaran yang ada, dapat dikatakan sudah memenuhi/ mewakili terha- dap semua perilaku yang terkait dengan pelanggaran hak cipta. Apalagi kalau dilihat dari segi ancaman pidananya, selalu ada peningkatan setiap kali ada perubahan undang: undang. Semula dengan Auteurswet 1912 delik hak cipta hanya diancam pidana denda. Dalam perjalanannya, dengan munculnya UU No.6 Tahun 1982, pelanggaran hak cipta tidak hanya diancam pidana denda tapi disertai juga pidana penjara. UU No.6 Tahun 1982 ini disempurnakan lagi dengan UU No.7 Tahun 1987. Kemudian ketiga Undang-undang terdahulu masih disempurnakan lagi dengan UU No.12 Tahun 1997.

Kalau dilihat ke belakang dapat ditelusuri mengapa Undang-undang di bidang Hak Cipta itu mengalami perubahan yang sangat cepat. Penyebab utama adalah tuntutan untuk menyesuaikan dengan perkembangan ekonomi dan teknologi yang bergitu cepat. Penyebab lain yang tidak kalah pentingnya adalah keikutsertaan Indonesia dalam konvensi-konvensi internasional di bidang Hak Atas Kekayaan Intelektual, yang menuntut dilakukannya penyesuaian-penyesuaian Undang-undang Hak Cipta Indonesia dengan konvensi-konvensi internasional tersebut.

Yang menjadi permasalahan adalah ada beberapa ketentuan di dalam konvensi-konvensi internasional itu yang tidak selaras dengan kondisi yang ada di Indonesia. Namun karena kita terikat dengan konvensi tersebut, maka mau tidak mau terpaksa Undang-undang Hak Cipta disesuaikan dengan konvensikonvensi tersebut.

\footnotetext{
"Soerjono Soekanto. Op.Cit. Hlm.2.

${ }^{12}$ Ibid. Him.5.
} 


\section{ad.2. Faktor Aparat Penegak Hukum}

Terdapat beberapa permasalahan berkaitan dengan faktor aparat penegak hukum dalam menegakkan Undang-undang Hak Cipta. Permasalahan tersebut berkaitan dengan keterbatasan jumlah aparat penegak hukum, kemampuan/skill yang dimiliki, dan pengetahuannya di bidang hak cipta. Perubahan sifat delik dari delik aduan menjadi delik biasa tentu saja menambah kuantitas pekerjaan aparat. Padahal seperti kita ketahui bahwa untuk menangani delik-delik konvensional saja masih kekurangan personil aparat, apalagi ditambah dengan delik non-konvensional seperti hak cipta ini.

Tingkat pengetahuan hukum dan kesadaran hukum aparat mengenai seluk beluk hak cipta juga masih rendah. Demikian juga halnya mengenai perubahan sifat delik hak cipta dari delik aduan menjadi delik biasa masih belum diketahui atau mendapat pemahaman secara merata di kalangan aparat. Mungkin saja mereka beranggapan bahwa pelanggaran hak cipta itu masih tetap delik aduan mengingat sifat delik itu lebih banyak mengarah ke privat. Dengan kondisi seperti ini wajar saja bila pelanggaran hak cipta semakin menggejala namun tindakan aparat belum cukup memadai.

Kemampuan/skill yang dimiliki aparat penegak hukum berkaitan dengan penyidikan hak cipta ini juga masih patut dipertanyakan. Mengingat delik ini sulit untuk dideteksi, dilakukan secara sembunyi-sembunyi dan terorganisir, serta dilakukan dengan menggunakan peralatan canggih sehingga sulit membedakan mana karya cipta yang asli dan mana karya cipta palsu. Antara keduanya hampir tidak terdapat perbedaan, bahkan kadang- kadang tidak tertutup kemungkinan karya cipta yang palsu justru menampakkan diri lebih sempurna dibandingkan karya cipta yang asli.

\section{ad.3. Faktor Sarana yang Tersedia}

Sebagaimana telah disebutkan di atas bahwa penggunaan teknologi canggih membuat sulitnya mendeteksi suatu pelanggaran hak cipta. Upaya yang dapat dilakukan adalah memperlengkapi sarana penegak hukum dengan peralatan yang canggih pula sehingga dapat mendeteksi pelanggaran hak cipta yang terjadi dalam masyarakat. Dalam realitasnya, sarana untuk penegakan hukum kita masih tergolong tidak memadai. Belum lagi kemampuan aparat penegak hukum yang juga masih rendah di dalam menangani pelanggaran hak cipta sebagaimana telah diuraikan di atas. Dengan kondisi yang demikian, kita tidak dapat berharap banyak dalam menanggulangi pelanggaran hak cipta.

\section{ad.4. Faktor Masyarakat}

Pengetahuan hukum dan kesadaran hukum masyarakat di bidang hak cipta dapat dikatakan masih rendah. Hal ini bisa dilihat dari masih sedikitnya masyarakat pencipta yang mendaftarkan haknya ke Departemen Kehakiman untuk mendapatkan perlindungan hukum terhadap pelanggaran hak cipta. Di samping itu juga masih banyak kita dapati pelanggaran hak cipta, namun pelanggaran itu tidak dilaporkan baik oleh pencipta maupun pemegang hak cipta kepada aparat penegak hukum. Banyak masyarakat masih beranggapan bahwa pelanggaran hak cipta adalah urusan pejabat penegak hukum semata-mata. Anggapan seperti itu perlu diubah supaya budaya enggan untuk melapor dapat menjadi 
budaya berperan aktif, untuk mengurangi sekecil mungkin ruang gerak pelaku tindak pidana hak cipta. ${ }^{13}$

Etika profesi dari kalangan masyarakat ilmuan juga merupakan faktor yang berpengaruh terhadap penegakan hukum. Melenturnya etika mengakibatkan dengan mudahnya orang untuk meniru hasil karya cipta orang lain tanpa seizin pencipta atau pemegang hak cipta. Juga mengenai bajak membajak hasil karya cipta orang lain dilakukan tanpa beban, hanya untuk mendapatkan materi yang banyak tanpa mau bersusah payah mengeluarkan tenaga dan waktu.

\section{ad.5. Faktor Budaya}

Faktor budaya ini juga memegang peranan di dalam penegakan hukum hak cipta. Hak cipta sebagai hak eksklusif (khusus) tidak mempunyai akar dalam kebudayaan Indonesia maupun dalam sistem hukum adat. Nilai falsafah yang mendasari pemilikan individu terhadap suatu karya cipta manusia baik dalam bidang ilmu, sastra maupun seni adalah nilai budaya barat yang menjelma dalam sistem hukumnya. ${ }^{14}$

Karena hak cipta tersebut bukan berasal dari nilai-nilai budaya bangsa Indonesia, tapi nilai-nilai barat yang menjelma dalam sistem hukum keperdataannya, kadangkala penerapan hak tersebut dalam kehidupan masyarakat menimbulkan pertentangan dengan nilai-nilai budaya tradisional yang melembaga dalam. kehidupan masyarakat. Artinya, ada perbuatan yang dikualifikasikan sebagai pelanggaran hak cipta menurut ketentuan Undang-undang, tapi dalam nilai-nilai budaya masyarakat tidak dianggap sebagai suatu pelanggaran hak cipta. ${ }^{15}$

\section{Simpulan}

Perlindungan hukum terhadap karya cipta seseorang sudah selayaknya mendapat perhatian serius mengingat arti pentingnya guna kemajuan di bidang ilmu pengetahuan, seni, dan sastra. Undang-undang Hak Cipta dapat dikatakan sudah cukup dalam hal pengaturan berkaitan dengan hak cipta ini. Namun, yang masih menjadi permasalahan di dalam realitasnya adalah berkaitan dengan penegakan terhadap Undang-undang tersebut oleh aparat penegak hukum, yang nampaknya masih menunjukkan hasil yang kurang optimal.

Terdapat beberapa faktor yang ditemukan di lapangan dalam kaitan dengan faktor-faktor penghambat penegakan hukum terhadap pelanggaran di bidang hak cipta ini. Setidaktidaknya ada lima faktor yang patut mendapatkan perhatian, yaitu: faktor undang-undang, faktor aparat penegak hukum, faktor sarana yang tersedia, faktor masyarakat, dan yang terakhir adalah faktor kebudayaan. Faktor-faktor tersebut besar pengaruhnya dan sangat menentukan sukses atau tidaknya penegakan hukum terhadap pelanggaran hak cipta.

\footnotetext{
${ }^{13}$ Sentosa Sembiring. 1986. Aspek-aspek Yuridis Dalam Penerbitan Buku. Bandung: Binacipta. Him.87.

${ }^{14}$ Salman Luthan. 1989. "Delik Hak Cipta". Makalah Diskusi Jurusan Hukum Pidana Fakultas Hukum Uil. Tanggal 24 Agustus 1989. Hlm.36.

15/bid. HIm. 37
} 


\section{Daftar Pustaka}

Gautama, Sudargo dan Rizawanto Winata. 1988. Konvensi-konvensi Hak Milik Intelektual Baru Untuk Indonesia (1997). Bandung: Citra Aditya Bakti.

Luthan, Salman. "Delik Hak Cipta". Makalah Diskusi Jurusan Hukum Pidana Fakultas Hukum UII. Tanggal 24 Agustus 1989.

Mahadi. 1982. "Peranan Kesadaran Hukum dalam Proses Penegakan Hukum". Kertas Kerja Simposium Penegakan Hukum di BPHN. Jakarta: Binacipta.

Marpaung, Leden. 1995. Tindak Pidana Terhadap Hak Atas Kekayaan Intelektual. Jakarta: Sinar Grafika.

Moeljatno. 1984. Asas-asas Hukum Pidana. Jakarta: Bina Aksara.

Poernomo, Bambang. 1984. Orientasi Hukum Acara Pidana. Yogyakarta: Amarta Buku.

1988. Kapita Selekta Hukum Pidana. Yogyakarta: Liberty.
Rahardjo, Satjipto. Tanpa Tahun. Masalah Penegakan Hukum Suatu Tinjauan Sosiologis. Bandung: Sinar Baru.

Sembiring, Sentosa. 1986. Aspek-aspek Yuridis Dalam Penerbitan Buku. Bandung: Binacipta.

Soekanto, Soerjono. 1983. Faktor-faktor yang Mempengaruhi Penegakan Hukum. Jakarta: Rajawali Pers.

Widyopramono. 1992. Tindak Pidana Hak Cipta Analisis dan Penyelesaiannya. Jakarta: Sinar Grafika.

Undang-undang No. 6 Tahun 1982 tentang Hak Cipta;

Undang-undang No.7 Tahun 1987 tentang Perubahan Atas Undang-undang No.6 Tahun 1982 tentang hak Cipta;

Undang-undang No.12 Tahun 1997 tentang Perubahan Atas Undang-undang No.6 Tahun 1982 tentang Hak Cipta sebagaimana telah diubah dengan Undang-undang No.7 Tahun 1987. 